\title{
Differential Response of Encapsulated Nucleus Pulposus Cells and Bone Marrow Derived MSCs in Isolation and Co-culture in Alginate and Chitosan Hydrogels
}

Syeda M. Naqvi, M.Sc. ${ }^{1,2}$ and Conor T. Buckley, Ph.D. ${ }^{1,2 *}$

${ }^{1}$ Trinity Centre for Bioengineering, Trinity Biomedical Sciences Institute, Trinity College Dublin, Ireland.

${ }^{2}$ Department of Mechanical Engineering, School of Engineering, Trinity College Dublin, Ireland.

Author: Syeda M. Naqvi

E-mail address: naqvis@tcd.ie

*Corresponding author: Conor T. Buckley

E-mail address: conor.buckley@tcd.ie

Address: Trinity Centre for Bioengineering

Trinity Biomedical Sciences Institute

Trinity College Dublin

Ireland

Telephone: +353-1-896-2061

Fax: +353-1-679-5554 


\section{Abstract}

Cell-based therapies may hold significant promise for the treatment of early stage degeneration of the intervertebral disc (IVD). Given their propensity to proliferate and ability to form multiple tissue types, mesenchymal stem cells (MSCs) have been proposed as a potential cell source to promote repair of the nucleus pulposus (NP). However, for any successful cell-based therapy a carrier biomaterial may be essential for targeted delivery providing key biophysical and biochemical cues to facilitate differentiation of MSCs. Two widely used biomaterials for NP regeneration are chitosan and alginate. The primary objective of this study was to assess the influence of alginate and chitosan hydrogels on bone marrow (BM) MSCs and NP cells in isolation or in co-culture. A secondary objective of this study was to investigate co-culture seeding density effects of BM and NP cells and simultaneously explore which cell type is responsible for matrix formation in a co-cultured environment. Porcine NP and BM cells were encapsulated in alginate and chitosan hydrogels separately at two seeding densities $\left(4 \times 10^{6}\right.$ and $8 \times 10^{6}$ cells $\left./ \mathrm{ml}\right)$ or in co-culture $\left(1: 1,8 \times 10^{6}\right.$ cells $/ \mathrm{ml}$ ). Constructs (diameter:5mm, height:3mm) were maintained under IVD-like conditions (low-glucose, low (5\%) oxygen) with or without TGF- $\beta 3$ supplementation for 21 days. Results demonstrated differential viability depending on hydrogel type. NP cells remained viable in both biomaterial types whereas BM viability was diminished in chitosan. Furthermore, hydrogel type was found to regulate sGAG and collagen accumulation. Specifically, alginate better supports sGAG accumulation and collagen type II deposition for both NP and BM cell types compared to chitosan. Having identified that alginate more readily supports cell viability and matrix accumulation we further explored additional effects of seeding density ratios (NP: BM - 1:1, 1:2) for co-culture studies. Interestingly, in coculture conditions, the BM cell population declined in number while NP cells increased indicating that MSCs may in fact be signalling NP cells to proliferate rather than contributing 
to matrix formation. These findings provide exciting new insights on the potential of MSCs for NP tissue regeneration strategies. 


\section{Introduction}

Degeneration of the intervertebral disc (IVD) is a normal part of the aging process, and is typically characterized by a loss in key extracellular matrix (ECM) components such as collagen and sulphated glycosaminoglycans (sGAG) which are responsible for maintaining tissue hydration thereby providing mechanical functionality. In addition, aging is associated with increased cellular senescence and changes in cellular phenotype that result in cells with decreased matrix synthesis capacity and/or altered matrix production (1-8).

Autologous Disc Cell Transplantation (ADCT) therapy has been proposed as a potential treatment for IVD degeneration (9) with recent studies in various animal models demonstrating that re-implantation of autologous nucleus pulposus (NP) cells delays degenerative changes in the disc $(10,11)$. However, the number of NP cells that can be harvested and expanded in vitro are insufficient to meet requirements for successful treatment (12). In addition, culturing primary NP cells for disc repair is challenging due to their limited expansion capability $(13,14)$. Furthermore, tissue harvesting may induce degeneration at the donor site or initiate degeneration in healthy IVDs (15). These issues have motivated the exploration of mesenchymal stem cells (MSCs) as an alternative cell source due to their propensity to proliferate and ability to form multiple tissue types $(16,17)$. MSCs possess significant potential and perhaps provide a more readily available and clinically feasible source of cells to promote the repair of NP tissue. In addition, in vivo studies have shown that implantation of MSCs into experimentally induced degenerate animal discs leads to improved disc height and accumulation of proteoglycans (18-20).

Several groups have explored co-culture systems of NP cells and MSCs since signalling between these cell types will ultimately occur in situ during MSC-mediated disc regeneration (21-24). However, there is still uncertainty regarding the exact mechanisms by which MSCs stimulate repair when transplanted into the IVD, as it may be due to 
differentiation of the injected MSCs themselves and/or stimulation of native resident NP cells.

For any cell-based therapy to be successful a carrier biomaterial may be required to prevent cell leakage, permit targeted delivery and to provide key biophysical and biochemical cues to facilitate differentiation of MSCs (12). Two naturally derived biomaterials widely used for biomedical applications include chitosan and alginate; both, by virtue of their properties and mild gelation conditions, have gained the acceptance of researchers as matrices for the purpose of cell based delivery strategies (25-28).

Alginate is a natural water soluble anionic polysaccharide which exhibits excellent biocompatibility and hydrophilic properties. It may be readily combined with cells to form a three-dimensional hydrogel structure under mild crosslinking conditions using calcium chloride $\left(\mathrm{CaCl}_{2}\right)$. Alginate has been shown to support a wide variety of cell types including NP cells (29-31) and MSCs (32, 33).

Chitosan is also a natural, however, cationic polymer and is theoretically superior to alginate in terms of biocompatibility and biodegradability. Previous work has demonstrated that chitosan can help restore the function of NP cells during the early stages of IVD degeneration (34) and that MSC-seeded chitosan gels may be used clinically for the regeneration of degenerated human IVD (17).

The primary objective of this study was to explore the influence of alginate and chitosan hydrogels on bone marrow derived MSCs (BM) and NP cells in isolation at two different cell seeding densities and in co-culture. A secondary objective of this study was to investigate co-culture seeding density effects of BM and NP cells and simultaneously explore which cell type is responsible for matrix formation in a co-cultured environment. 


\section{Methods}

Nucleus pulposus (NP) cell isolation and culture

Intervertebral discs (IVDs) from the lumbar region were harvested from the spine of porcine donors $(\mathrm{N}=3,3-4$ months, 20-30kg) within three hours of sacrifice. Under aseptic conditions, IVDs were carefully exposed and the gelatinous nucleus pulposus tissue removed from the central section of the disc. To confirm the absence of bacterial growth, dissected tissue was cultured overnight at $37^{\circ} \mathrm{C}, 5 \% \mathrm{CO}_{2}$ in a humidified atmosphere in serum-free low-glucose Dulbecco's Modified Eagles Medium (LG DMEM, 1 g/L D-glucose) supplemented with antibiotics/antimycotics (100U/ml penicillin, $100 \mu \mathrm{g} / \mathrm{ml}$ streptomycin). NP tissue was enzymatically digested in $2.5 \mathrm{mg} / \mathrm{ml}$ pronase solution for 1 hour followed by 4 hours in $0.5 \mathrm{mg} / \mathrm{ml}$ collagenase solution at $37^{\circ} \mathrm{C}$ under constant rotation in serum free LG DMEM containing antibiotic/antimycotics (100U/ml penicillin, $100 \mu \mathrm{g} / \mathrm{ml}$ streptomycin). Digested tissue/cell suspension was passed through a $100 \mu \mathrm{m}$ cell strainer to remove tissue debris followed by $70 \mu \mathrm{m}$ and $40 \mu \mathrm{m}$ cell strainers to separate notochordal cells (NC) from the desired nucleus pulposus cells (NP) as previously described (35). Cells were then washed three times by repeated centrifugation at $650 \mathrm{G}$ for 5 minutes. NP cells were cultured to confluence in T-75 $\mathrm{cm}^{2}$ flasks with LG DMEM, supplemented with $10 \%$ Foetal bovine serum (FBS), 100U/ml penicillin, $100 \mu \mathrm{g} / \mathrm{ml}$ streptomycin, $2.5 \mu \mathrm{g} / \mathrm{ml}$ amphotericin $\mathrm{B}, 5 \mathrm{ng} / \mathrm{ml}$ Fibroblast Growth Factor-2 (FGF-2; ProSpec-Tany TechnoGene Ltd, Israel) at $37^{\circ} \mathrm{C}$ in a humidified atmosphere containing $5 \% \mathrm{CO}_{2}$, and expanded to passage $2(\mathrm{P} 2)$ with medium exchanges performed every 3 days.

\section{Bone marrow (BM) derived MSC isolation and culture}

Donor matched bone marrow-derived stem cells $(\mathrm{BM})$ were isolated from the femora of porcine donors $(\mathrm{N}=3,3-4$ months, $20-30 \mathrm{~kg})$ within 3 hours of sacrifice as previously 
described (36). Briefly, mononuclear cells were isolated from the femora and plated at $10 \times 10^{6}$ cells in $\mathrm{T}-75 \mathrm{~cm}^{2}$ flasks to allow for colony formation (P0). MSCs were maintained in low-glucose Dulbecco's Modified Eagles Medium (LG DMEM, 1 g/L D-glucose) supplemented with $10 \%$ foetal bovine serum (FBS), penicillin $(100 \mathrm{U} / \mathrm{ml})$-streptomycin $(100$ $\mu \mathrm{g} / \mathrm{ml}$ ) (all GIBCO, Invitrogen, Dublin, Ireland) and amphotericin B $(0.25 \mu \mathrm{g} / \mathrm{ml}$, SigmaAldrich, Arklow, Ireland). After P0, MSCs were re-plated at $5 \times 10^{3}$ cells $/ \mathrm{cm}^{2}$ and expanded to passage two (P2) in a humidified atmosphere at $37^{\circ} \mathrm{C}$ and $5 \% \mathrm{CO}_{2}$.

\section{Alginate Hydrogel Encapsulation}

Expanded cells (NP and BM) were trypsinised and counted using trypan blue staining and encapsulated in $1.5 \%$ alginate (Pronova UP LVG, FMC NovaMatrix, Norway) in isolation at two different cell seeding densities $\left(4 \times 10^{6}\right.$ cells $/ \mathrm{ml}$ and $8 \times 10^{6}$ cells $\left./ \mathrm{ml}\right)$ and in $1: 1 \mathrm{NP}$ to BM ratio maintaining the concentration of NP at $4 \times 10^{6}$ cells $/ \mathrm{ml}$ to yield a final concentration of $8 \times 10^{6}$ cells $/ \mathrm{ml}$. For alginate co-culture studies two different $\mathrm{NP}$ to $\mathrm{BM}$ ratios were investigated (NP: BM - 1:1, 1:2) resulting in final cell densities of $8 \times 10^{6}(1: 1)$ and $12 \times 10^{6}$ (1:2) cells/ml. Alginate/cell suspensions were pipetted into $3 \%$ agarose/100mM $\mathrm{CaCl}_{2}$ cylindrical moulds, slabs of the same were mounted onto the wells to allow gelation from the top as well and gels were allowed to ionically crosslink at $37^{\circ} \mathrm{C}$ for 30 minutes to form cylindrical constructs $(\varnothing 5 \mathrm{xH} 3 \mathrm{~mm})$.

\section{Chitosan hydrogel encapsulation}

Expanded cells (NP and BM) were trypsinised and counted using trypan blue staining and encapsulated in $1.5 \%$ chitosan (Protasan UP CL 214, FMC NovaMatrix, Norway) in isolation at two different cell seeding densities $\left(4 \times 10^{6}\right.$ cells $/ \mathrm{ml}$ and $8 \times 10^{6}$ cells $\left./ \mathrm{ml}\right)$ and in $1: 1$ $\mathrm{NP}$ to $\mathrm{BM}$ ratio maintaining the concentration of $\mathrm{NP}$ at $4 \times 10^{6}$ cells $/ \mathrm{ml}$ to yield a final 
concentration of $8 \times 10^{6}$ cells $/ \mathrm{ml}$. Chitosan was dissolved in ultra-pure water (UPW) to create a $3 \%(\mathrm{w} / \mathrm{v})$ solution and autoclaved to render sterile. Chitosan solution was mixed with a concentrated stock solution of filter-sterilized B-glycerophosphate (B-Gly), to yield a liquid chitosan/B-Gly solution $(\mathrm{pH}=6.9)$. Cells were re-suspended in LG chemically defined medium and mixed with filter-sterilized hydroxyethyl cellulose (HEC) to form a cell/HEC solution. Both solutions were homogeneously mixed and allowed to set at $37^{\circ} \mathrm{C}$ for 30 minutes in $3 \%$ agarose moulds to form cylindrical constructs $(\varnothing 5 \mathrm{xH} 3 \mathrm{~mm})$.

\section{Hydrogel culture}

Alginate and chitosan constructs were cultured under identical conditions. Briefly, constructs were maintained in a chemically defined medium $(C D M)$ consisting of low glucose $(1 \mathrm{~g} / \mathrm{L})$ medium supplemented with penicillin $(100 \mathrm{U} / \mathrm{ml})$-streptomycin $(100 \mu \mathrm{g} / \mathrm{ml})$ (both GIBCO, Biosciences, Ireland), $100 \mu \mathrm{g} / \mathrm{ml}$ sodium pyruvate, $40 \mu \mathrm{g} / \mathrm{ml} \mathrm{L-proline,} 50 \mu \mathrm{g} / \mathrm{ml} \mathrm{L}$-ascorbic acid-2-phosphate, $1.5 \mathrm{mg} / \mathrm{ml} \mathrm{BSA,} 1 \times$ insulin-transferrin-selenium, $100 \mathrm{nM}$ dexamethasone (all from Sigma-Aldrich, Ireland) and $10 \mathrm{ng} / \mathrm{ml}$ recombinant human transforming growth factor- $\beta 3$ (TGF- $\beta 3$; ProSpec-Tany TechnoGene Ltd, Israel). Hydrogel constructs were cultured in standard 12 well plates with one construct per well in a low oxygen $(5 \%)$ environment as previously described (37). Each construct was maintained in $2 \mathrm{~mL}$ of supplemented medium with complete medium exchanges performed twice weekly for the total culture duration of 21 days. Constructs were assessed at days 0 and 21 in terms of cell viability, biochemical content (DNA, sulfated-glycosaminoglycan (sGAG) and collagen content) and histologically. 


\section{Cell viability, Fluorescent cell labelling and Cell Counting}

For non-fluorescence labelled groups, cell viability was assessed using a LIVE/DEAD® Viability/Cytotoxicity Assay Kit (Invitrogen, Bio-science, Ireland). At day 0 and day 21, a single construct from each group was removed from culture and cut in half, rinsed three times with PBS and incubated for 1 hour at $37^{\circ} \mathrm{C}$ in live/dead solution containing $2 \mu \mathrm{M}$ calcein $\mathrm{AM}$ and $4 \mu \mathrm{M}$ ethidium homodimer-1 (EthD-1). After incubation, segments were washed three times with PBS and imaged with an Olympus FV-1000 Point-Scanning Confocal Microscope (Southend-on-Sea, UK) at 488 and $543 \mathrm{~nm}$ channels and analysed using FV10-ASW 2.0 Viewer software.

PKH67 and PKH26 Fluorescent Cell Linker Kits (Sigma-Aldrich, Ireland) were used to label the cell membrane of NP and $\mathrm{BM}$ cell populations for use in alginate co-culture studies comparing two different cell ratios (NP: BM -1:1, 1:2). Both cell types were labelled separately; BM cells were stained with PKH67 and NP cells were stained with PKH26. The cell suspension of desired concentration and the dye solution (both in a diluent supplied with the kit) were mixed and incubated briefly at room temperature. The labelling reaction was terminated by addition of FBS. Labelled cells were washed 3 times with complete medium to remove unbound dye. All steps were performed at room temperature in accordance with the manufacturer's instructions (Sigma-Aldrich Corporation, St. Louis, MO, USA). For these fluorescent cell labelled groups, constructs were incubated for 1 hour at $37^{\circ} \mathrm{C}$ in live/dead solution containing $3 \mu \mathrm{M}$ Draq-7 which stains nuclei in dead cells. Its far-red emission (665 $\mathrm{nm}$ and beyond) permits its use in parallel with that of PKH labels. Day 0 and day 21 gels were imaged with an Olympus FV-1000 Point-Scanning Confocal Microscope (Southend-onSea, UK) at 546, 488 and $663 \mathrm{~nm}$ channels and analysed using FV10-ASW 2.0 Viewer software. 
For cell counting of fluorescently labelled co-culture groups, the images were separated so that each cell type was visible in isolation; a separate image was used to count each cell type. Briefly, the captured image of the cross-section of the gel was overlaid with a $5 \times 3$ grid pattern with each grid equivalent to $1 \mathrm{~mm}^{2}$ of gel area. Three fields of view were chosen in a diagonal pattern across the image.

\section{Quantitative biochemical analysis}

Samples were digested with papain $(125 \mu \mathrm{g} / \mathrm{ml})$ in $0.1 \mathrm{M}$ sodium acetate, $5 \mathrm{mM}$ L-cysteine $\mathrm{HCl}$, and 0.05 M EDTA (Sigma-Aldrich, Ireland) at $60^{\circ} \mathrm{C}$ under constant agitation for 18hours. Alginate samples were digested in papain $(\mathrm{pH}$ 6.5) and chitosan samples were digested in papain (pH 7.5) (38). DNA content was quantified using the Quant-iT PicoGreen dsDNA kit (Molecular Probes, Biosciences, Ireland) with a lambda DNA standard. Proteoglycan content was estimated by quantifying the amount of sulphated glycosaminoglycan (sGAG) in constructs using the dimethylmethylene blue dye-binding assay (DMMB Blyscan, Biocolor Ltd., Northern Ireland), with a chondroitin sulphate standard. Total collagen content was determined by measuring the hydroxyproline content. Samples were hydrolysed at $110^{\circ} \mathrm{C}$ for 18 hours in concentrated hydrochloric acid $(\mathrm{HCl})$ (38\%) and assayed using a chloramine-T assay (39), using a hydroxyproline-to-collagen ratio of 1:7.69 (40). Due to the interference of chitosan with the DNA assay $(38,41)$ and to allow comparisons to be made with alginate hydrogels, biochemical data (sGAG and collagen) is normalised on a per cell basis in figures 2 and 4 .

\section{Histology and immunohistochemistry}

Constructs were fixed in $4 \%$ paraformaldehyde (PFA) overnight, dehydrated in a graded series of ethanol, embedded in paraffin wax, sectioned at $8 \mu \mathrm{m}$ and affixed to microscope 
slides. Sections were stained for glycosaminoglycans (GAGs) using aldehyde fuschin and 1\% alcian blue 8GX (Sigma-Aldrich, Ireland) in $0.1 \mathrm{M} \mathrm{HCl}$ (42). The deposition of collagen types I and II were identified through immunohistochemistry. Briefly, sections were quenched of peroxidase activity, rinsed with PBS before treatment with chondroitinase ABC in a humidified environment at $37^{\circ} \mathrm{C}$. Slides were rinsed with PBS and non-specific sites were blocked with goat serum. Sections were then incubated for 1 hour at $4^{\circ} \mathrm{C}$ with the primary antibody; collagen type I (ab6308) $(1: 200 ; 1 \mathrm{mg} / \mathrm{ml})$ or collagen type II (ab3092) $(1: 80 ; 1 \mathrm{mg} / \mathrm{ml})$ antibodies (mouse monoclonal, Abcam, Cambridge, UK). After washing in PBS, sections were incubated for 1 hour in the secondary antibody; anti-mouse IgG biotin antibody produced in goats $(1: 133 ; 2.1 \mathrm{mg} / \mathrm{ml})$. Colour was developed using the Vectastain $\mathrm{ABC}$ reagent followed by exposure to peroxidase $\mathrm{DAB}$ substrate kit. Negative and positive controls of porcine ligament and cartilage were included for each batch.

\section{Statistical analysis}

Statistical analyses were performed using GraphPad Prism (version 4) software with 6 samples analysed for each experimental group. Two-way ANOVA was used for analysis of variance with Bonferroni post-tests to compare between groups. Numerical and graphical results are displayed as mean \pm standard deviation. Significance was accepted at a level of $p$ $<0.05$. 


\section{Results}

Bone marrow (BM) cell viability is dependent on hydrogel type

For both alginate and chitosan, NP encapsulated gels increased in DNA content for both seeding densities (Fig 1A). Results from DNA analysis were confirmed through confocal imaging of live and dead cells (Fig 1B). NP cell viability was maintained in both hydrogels for both cell seeding densities $\left(4 \times 10^{6}\right.$ and $8 \times 10^{6}$ cells $\left./ \mathrm{ml}\right)$ (Fig 1A). It may be noted that an increased number of dead cells (yellow/red) were observed in the NP 4x $10^{6}$ cells $/ \mathrm{ml}$ chitosan construct compared with NP $8 \times 10^{6}$ cells $/ \mathrm{ml}$. For BM alginate constructs an increase in DNA content was observed compared to day 0. However, for BM encapsulated chitosan constructs, DNA content significantly decreased from day 0 to day 21 for both cell seeding densities $\left(4 \times 10^{6}\right.$ and $8 \times 10^{6}$ cells $\left./ \mathrm{ml}\right)$. Also, we observed less proliferation and a minor increase of dead cells in the $\mathrm{BM} 8 \times 10^{6}$ cells $/ \mathrm{ml}$ alginate construct compared to the $\mathrm{BM} 4 \times 10^{6}$ cells $/ \mathrm{ml}$. In addition, a change in cell morphology was observed for NP and BM encapsulated chitosan constructs whereby rounded cells became more spread-like by day 21 compared to day 0 and for alginate hydrogels, the rounded cell morphology of both NP and BM cells was maintained (Fig. S1).

Alginate better supports sGAG accumulation and collagen type II deposition compared to chitosan for NP and BM cell types

sGAG content normalised on a per cell basis was significantly higher in alginate compared to chitosan for both NP and BM and for both cell seeding densities (Fig 2A). This difference was also observed when sGAG was normalised to wet weight (Fig 2B). There was no difference observed in collagen content normalised on a per cell basis between the two hydrogel types (Fig 2C). However, when normalised to wet weight, chitosan displayed significantly greater collagen content compared to alginate for both NP and BM and for both 
cell seeding densities (Fig 2D). This may be explained by the differences in weights between alginate and chitosan hydrogels whereby chitosan gels were approximately half the weight of alginate hydrogels. The GAG:Collagen ratio was also found to be higher for alginate hydrogels compared to chitosan (Fig 2E) approaching that of native NP tissue where the GAG to collagen ratio is as high as 3.5:1 (43).

Increased seeding density resulted in significantly increased sGAG accumulation in both alginate and chitosan for both NP and BM cell types (Fig 2B). Similar results were obtained for collagen accumulation, however, BM-encapsulated chitosan at $8 \times 10^{6}$ cells $/ \mathrm{ml}$ displayed significantly less collagen content compared to $4 \times 10^{6}$ cells/ml (Fig 2D). Also, the GAG:Collagen ratio was found to be greater for BM-encapsulated alginate and NPencapsulated chitosan in higher seeding density groups compared to lower seeding density groups (Fig 2E).

Histological evaluation demonstrated greater sGAG accumulation and robust collagen II deposition in alginate compared to chitosan (Fig 3). Aldehyde fuschin/alcian blue staining revealed greater sGAG accumulation in alginate (Fig 3A-3D) constructs for both NP and BM at both cell seeding densities $\left(4 \times 10^{6}\right.$ cells $/ \mathrm{ml}$ and $8 \times 10^{6}$ cells $\left./ \mathrm{ml}\right)$ compared to chitosan constructs (Fig 3E-3H). Immunohistochemistry for collagen type I exhibited limited deposition in BM encapsulated alginate constructs at both seeding densities (Fig 3K and L). For NP encapsulated alginate constructs, collagen type I deposition was observed in the higher seeding density group only (Fig 3I and J). In addition, chitosan suppressed collagen type I accumulation for the same groups (Fig 3M-3P). Robust collagen type II deposition was observed in alginate for $\mathrm{NP}$ and $\mathrm{BM}$ in isolation at both seeding densities compared to chitosan (Fig 3Q-3X). Constructs maintained in medium without TGF- $\beta 3$ supplementation resulted in negligible accumulation of matrix (data not shown). 


\section{Alginate better supports matrix formation in co-culture of NP and BM cells.}

DNA content of co-cultured constructs significantly increased from day 0 to day 21 in chitosan compared to alginate (Fig 4A). However, sGAG content normalised on a per cell basis was significantly higher in alginate compared to chitosan (Fig 4B) and this difference was also observed when total sGAG is normalised to wet weight (Fig 4C). In addition, collagen content, normalised on a per cell basis, was significantly increased in alginate (Fig 4B). However, when collagen is normalised to wet weight chitosan exhibited significantly higher collagen content compared to alginate (Fig 4C). As highlighted earlier, this is most likely due to the difference in weights between alginate and chitosan hydrogels whereby the chitosan hydrogels were approximately half the weight of the alginate hydrogels. GAG:Collagen ratio was also found to be higher in alginate compared to chitosan (Fig 4D).

Results from DNA analysis were supported by confocal imaging of live and dead cells with greater cell proliferation occurring in chitosan. Aldehyde fuschin/alcian blue staining revealed greater sGAG accumulation in alginate constructs (Fig 4F). Immunohistochemistry results revealed limited collagen type I accumulation for either alginate or chitosan hydrogels (Fig 4G). Immunohistochemistry results demonstrated robust collagen type II deposition in alginate compared to chitosan (Fig $4 \mathrm{H})$. Constructs maintained in medium without TGF- $\beta 3$ supplementation resulted in negligible accumulation of matrix (data not shown).

\section{BM cells decreased in number and NP cells proliferated in co-culture conditions}

DNA content of the 1:2 co-culture constructs significantly increased from day 0 to day 21 reaching a maximum of $268.8 \pm 11.2 \%$ compared to $1: 1$ co-culture constructs with $127.3 \pm$ $5.2 \%$ (Fig 5A). Cell labelling illustrated BM cells decreased in number and NP cells proliferated from day 0 to day 21 for both $1: 1$ and 1:2 co-culture groups (Fig 5B). This was 
confirmed through semi-quantitative analysis (Fig 5C); a cell count of NP and BM cells illustrated a significant increase in NP cell number from day 0 to day 21 for both 1:1 and 1:2 co-culture groups with approximately 2 fold and 4 fold increases, respectively. An average of $391.67 \pm 8.62$ for NP and $108 \pm 14$ for $\mathrm{BM}$ were counted per field of view at day 21 for $1: 1$ ratio and $454.3 \pm 5.86$ for $\mathrm{NP}$ and $55.3 \pm 18.15$ for $\mathrm{BM}$ for $1: 2$ ratio. A significant decrease in BM cell number was observed with a $24.7 \%$ percentage decrease in the $1: 1$ co-culture group and a $73.8 \%$ percentage decrease in the $1: 2$ co-culture group from day 0 to day 21 . Of note, cell viability was maintained in all groups (data not shown).

\section{Effect of co-culture cell ratio on matrix accumulation}

Biochemical analysis showed increased total sGAG in 1:2 co-culture group compared to $1: 1$ group (Fig 6A). Similar results were obtained when sGAG was normalised to wet weight and to DNA (Fig 6B and 6C). It may be noted that, although the ratio of BM to NP is double in the 1:2 co-culture group, the increase in sGAG is not doubled compared to the $1: 1$ co-culture group. No difference was found in total collagen content between 1:1 and 1:2 co-culture groups (Fig 6A-6C). Increased sGAG:Collagen was obtained for 1:2 compared to 1:1 (Fig 6D). Histological evaluation confirmed biochemical analysis findings illustrating greater sGAG accumulation in 1:2 compared to 1:1 constructs (Fig 6E). Immunohistochemistry results revealed no differences in the amount of collagen accumulation in 1:2 compared to 1:1 constructs, although there appears that more collagen type II was deposited compared to type I (Fig 6E). Constructs maintained in media without TGF- $\beta 3$ supplementation resulted in negligible matrix accumulation (data not shown). Also, it should be noted that this experiment was performed on alginate constructs only. 


\section{Discussion}

Previous studies have shown that NP and BM cells remain viable, proliferate and synthesise matrix (collagen type II and GAG) in alginate $(30,31,47-50)$ and chitosan $(17,34$, 51). In our hands and culture conditions, alginate more readily maintained and supported NP and $\mathrm{BM}$ cell viability with increased cell proliferation compared to chitosan at both seeding densities when cultured in isolation. At the lower seeding density $\left(4 \times 10^{6} / \mathrm{ml}\right)$ for NP chitosan we observed yellow cells in the live/dead imaging indicative of cells undergoing cell death and at the higher seeding density $\left(8 \times 10^{6} / \mathrm{ml}\right)$ for NP chitosan, there was an increased number of dead cells. This may be a time lag effect due to initial seeding density whereby given further time the $4 \times 10^{6} / \mathrm{ml}$ NP chitosan constructs would result in increased cell death to the same extent as the $8 \times 10^{6} / \mathrm{ml} \mathrm{NP}$ chitosan group. Additionally, alginate supported greater accumulation of sGAG and increased collagen II deposition compared to chitosan yielding a higher GAG:Collagen ratio approaching that of native porcine NP tissue. The production of a high GAG:Collagen ratio may provide an appropriate metric of identifying an NP-like tissue type. If stem cells are to be differentiated towards a disc cell phenotype, it will be essential to verify that the ultimate matrix that they produce has an appropriate GAG to collagen ratio which, for native NP, is approximately 3.5:1 (43). While this ratio may not help in determining whether ultimate differentiation has occurred, it provides an indication for the correct composition of the tissue that the cells produce (43).

Alginate maintained the typical rounded cell morphology of NP cells suggesting that the NP cell phenotype was preserved throughout culture. This may explain the improved accumulation of matrix observed in alginate compared with chitosan since a change in NP cell morphology from round to a more spread-like shape in chitosan hydrogels was observed possibly suggesting a change in cell phenotype. This is in agreement with several studies which have previously shown that NP cells remain phenotypically stable in alginate 
throughout the culture period $(47,48)$. Since chitosan is a cationic polymer NP and BM cells adhered to it and developed focal adhesions as compared to alginate, which is an anionic polymer and does not permit cell adhesion or binding. It is well known that cell shape and spreading are influential in regulating stem cell proliferation and differentiation (52-55). In general a more rounded cell type lends itself to a more chondrogenic like phenotype producing higher amounts of sGAG and collagen type II (56). In comparison a spread morphology, as observed for chitosan, results in a more fibroblastic like cell producing less sGAG and more collagen type I. Interestingly, Dadsetan et al. reported that significantly enhanced production of chondrocyte-specific proteins was induced when chondrocytes were cultured on negatively charged hydrogels (53). This is in agreement with results obtained in this study; alginate, a naturally occurring anionic polymer, supported the production of sGAG and collagen type II. Furthermore, we hypothesize that perhaps positively charged chitosan decreased the adhesive activity of BM MSCs in this study and this unstable adhesion state might have led to increased cell death and as a result the BM MSC population formed limited extracellular matrix. In addition, previous work has shown that biomaterial type strongly influences cell metabolism or nutrient demands of encapsulated cells (57). Interestingly, NP viability was maintained in chitosan hydrogels in contrast to BM cells which decreased in viability. It should be noted that in this work, a low oxygen and low glucose culturing regime was utilised to simulate the microenvironment of the IVD. BM cells may have a higher nutrient requirement compared to NP cells which may adapt more readily to these conditions. Further studies on the effects of biomaterial type on oxygen and glucose nutrient demands warrant further investigations.

When NP and BM cells were co-cultured in a 1:1 NP:BM ratio, alginate more readily supported matrix accumulation compared to chitosan, however, compared with NP and BM cell encapsulated alginate in isolation there was no significant difference in matrix 
accumulation. This is similar to the findings by Le Visage and colleagues who employed a 3D co-culture system, and established that a random mixture of MSC and degenerative NP cells did not increase GAG production beyond single-cell type controls (23). However, this is in contrast to previous work by Gaetani et al, of NP cells and adipose tissue derived nonadipocyte fraction cells (nAFs) in an alginate co-culture system demonstrating improved quality of the in vitro reconstructed tissue in terms of extracellular matrix production and 3D cell organization (59). Another study by Yamamoto reported significant increases in proteoglycan synthesis and cell proliferation when non-degenerative NP cells and MSCs were cultured with direct cell-cell contact (21). This leads to question the exact mechanisms by which MSCs stimulate repair when transplanted into the IVD, as it may be due to differentiation of the injected MSCs themselves and/or stimulation of native endogenous NP cells. 2D co-culture systems have previously demonstrated that NP cells induce MSCs to differentiate into an NP-like phenotype as assessed by gene expression (22). Also, Vadala et al have shown that 3D unstructured co-cultures of MSCs and NP cells up regulated key differentiation markers in MSCs (24). However, previous work of human MSC:NP co cultures has shown that the interaction is a dual process with MSCs differentiating towards an NP-like phenotype and the NP degenerate cell population regaining the ability to secrete new matrix (60). It has previously been established that the mode of culture condition (i.e. direct or indirect) can significantly influence the response of MSCs. Specifically, direct co-culture has been shown to stimulate MSC differentiation and indirect co-culture appears to stimulate MSCs to release trophic factors. Scuteri et al demonstrated that direct contact between MSCs and pancreatic islets was able to trigger the differentiation of MSCs and indirect co-cultures resulted in increased cell survival of the pancreatic islets' possibly mediated by the trophic factors released by MSCs (61). The present study suggests that under indirect 3D hydrogel co-culture conditions (i.e. cells do not appear to have cell-cell contact when encapsulated in a 
hydrogel), BM MSCs act as supporting cells, which enhance the ability of NP cells to proliferate and secrete matrix. This is in agreement with the work of Richardson et al. who showed that in direct co-culture (2D monolayer system) of NP and MSCs that MSCs differentiated into an NP-like phenotype and indirect co-cultures (separation of MSCs and NP cells through a semi-permeable membrane) had no effect on MSC differentiation (22). It is most likely that indirect co-culture of MSCs and NP exert a trophic effect on the NP cell population by secreting important growth factors such as cartilage-derived morphogenetic protein-1 (CDMP 1), transforming growth factor beta-1 (TGF- $\beta 1$ ), insulin-like growth factor 1 (IGF-1) and connective tissue growth factor (CTGF) which have been previously reported (60).

It is well established that in a degenerated IVD, the number of resident cells is reduced and the ability of viable NP cells to generate new matrix is diminished. Whether the implantation of MSCs can rescue the NP phenotype of degenerated NP cells to secrete new matrix in vivo warrants further investigation. An important key question with MSC based regeneration strategies is to identify the optimal number of MSCs that may be required to elicit a positive response. In this work, when the number of BM MSCs was increased by a factor of two in alginate co-culture, higher accumulation of sGAG was observed although the increase was not proportional to the initial seeding ratio. Interestingly, based on the results from cell labelling experiments, the BM population diminished with time, with NP cells increasing in number. This suggests that the NP cell population is most likely responsible for any matrix accumulation observed in the co-culture system investigated in this work. This finding highlights important questions as to the exact role and efficacy of implanting MSCs for IVD repair. The observation that there was limited benefit to increasing the number of BM to NP cells by a factor of two is important from a clinical viewpoint whereby obtaining 
sufficient cell yields may pose an issue and may not be required to elicit a beneficial response.

There are inherent limitations of using porcine tissue as a model for NP given that porcine tissue contains a population of notochordal cells which respond differently to adult NP cells (62). In early foetal life, human NP contains clusters of large vacuolated cells, called notochordal cells which are later replaced by smaller cells of chondrocyte-like appearance seen in the adult NP $(63,64)$. However, in pigs these notochordal cells persist well into adulthood and even throughout life (4). In an attempt to separate nucleus pulposus (NP) cells from notochordal (NC) cells during the cell isolation steps by way of filtration; we isolated NP cells by filtering through a $40-\mu \mathrm{m}$ cell strainer and collecting the filtrate. This is in contrast to the protocol described by Spillekom's (35) where NCs were collected by reverse rinsing a $40-\mu \mathrm{m}$ cell strainer after the cell suspension was filtered through it and the clusters of NCs remained in the strainer. Morphological examinations of the freshly isolated NP cells revealed that the cell population primarily consisted of spindle like cells which is a key characteristic of NP cells (data not shown). Unlike the NCs, NP cells have a relatively uniform phenotype with a rounded nucleus. NCs are mostly organized in large clusters and almost the entire NC volume is occupied by vacuoles. Also, NC nuclei appear quite irregular in shape and size (35). Another limitation of this work is the absence of a single cell type control for the 1:2 co-culture alginate group. However, for BM cells cultured in isolation at either $4 \times 10^{6}$ or $8 \times 10^{6}$ cells $/ \mathrm{ml}$, these cells were observed to maintain viability, proliferate, producing sGAG and collagen over 21 days when encapsulated in alginate. However when in co-culture at $1: 1\left(4 \times 10^{6} \mathrm{BM}\right.$ cells $)$ or $1: 2\left(8 \times 10^{6} \mathrm{BM}\right.$ cells $), \mathrm{BM}$ cells did not proliferate and reduced in number over the 21 day period of culture. Also, it is unlikely that the decrease in $\mathrm{BM}$ numbers is due to nutrient limitations alone since no variation in spatial distribution 
(periphery to central region) of cell viability for either NP or BM cells was observed at the higher seeding ratio of $1: 2$.

Taken together these results suggest that alginate supports MSC viability to a higher extent compared to chitosan when cultured under IVD like conditions in isolation and in coculture. It is important for future studies to consider the co-culture conditions being adopted (either direct or indirect) when assessing biomaterial types as this will influence the behaviour or response of MSCs. If the intended function of implanted MSCs is to differentiate towards an NP-like phenotype rather than acting as a supporting cell type, producing trophic factors, then a direct co-culture with cell-cell contact may be required. In this work, we found that in indirect co-culture (i.e. NP and BM cells do not appear to have cell-cell contact in 3D alginate hydrogel) MSCs acted as supporting cells enhancing NP proliferation and subsequent matrix production by NP cells. Furthermore, the observation that there is limited benefit to increasing the number of BM to NP cells by a factor of two is important from a clinical viewpoint whereby obtaining sufficient cell yields may pose an issue and may not be required to elicit a beneficial response. Whether these findings would translate to an in vivo scenario of disc degeneration is unknown and warrants further investigation.

\section{Acknowledgements}

This work was supported by the Graduate Research Education Programme in Engineering (GREP-Eng), PRTLI Cycle 5 funded programme. PRTLI is 50\% co-funded under the European Regional Development Fund.

\section{Author Disclosure Statement}

No competing financial interests exist. 
Figure legends
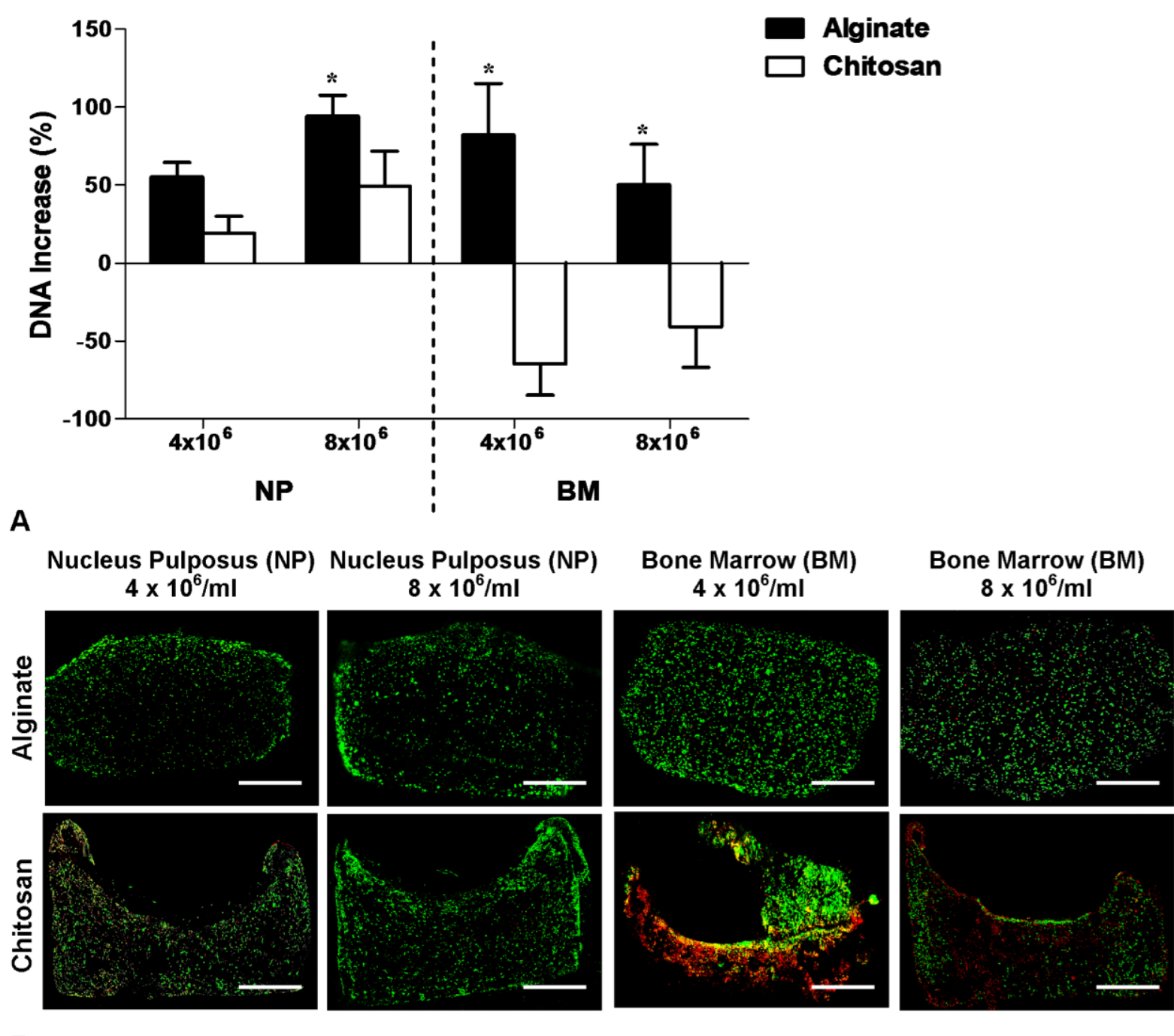

B

Fig. 1: (A) Percentage DNA increase at day 21 for nucleus pulposus (NP) and bone marrow stem cells $(\mathrm{BM})$ at two different cell seeding densities $\left(4 \times 10^{6}\right.$ cells $/ \mathrm{ml}$ and $8 \times 10^{6}$ cells $\left./ \mathrm{ml}\right)$, * denotes significance; $\mathrm{p}<0.05$ compared to chitosan for same given seeding density; data represents mean \pm SD ( $n=6)$. (B) Cell Viability; Green Fluorescence indicates viable cells (Calcein) and red indicates dead cells (Ethidium Homodimer-1). Scale bar $=1 \mathrm{~mm}$. 

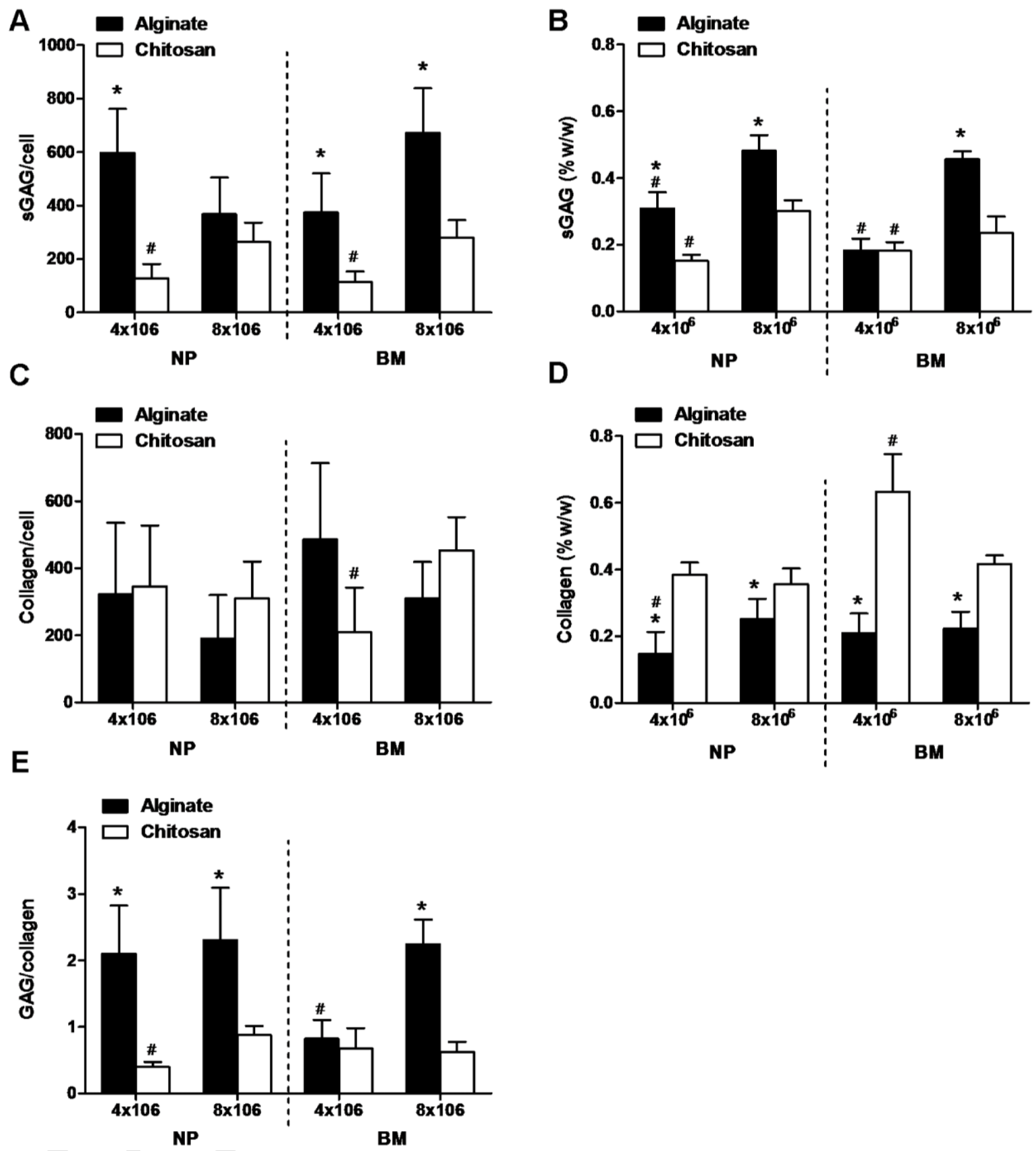

Fig. 2: Biochemical analysis at day 21 for nucleus pulposus (NP) and bone marrow stem cells (BM) at two different cell seeding densities $\left(4 \times 10^{6}\right.$ cells $/ \mathrm{ml}$ and $8 \times 10^{6}$ cells $\left./ \mathrm{ml}\right) ;(\mathrm{A}) \mathrm{sGAG}$ content normalised on a per cell basis; (B) sGAG normalized to wet weight; (C) Collagen content normalised on a per cell basis; (D) Collagen normalised to wet weight and (E) sGAG/Collagen ratio. * denotes significance compared to chitosan $(\mathrm{p}<0.05)$; \# denoted significance compared to $8 \times 10^{6}$ cell/ml seeding density group $(\mathrm{p}<0.05)$. 


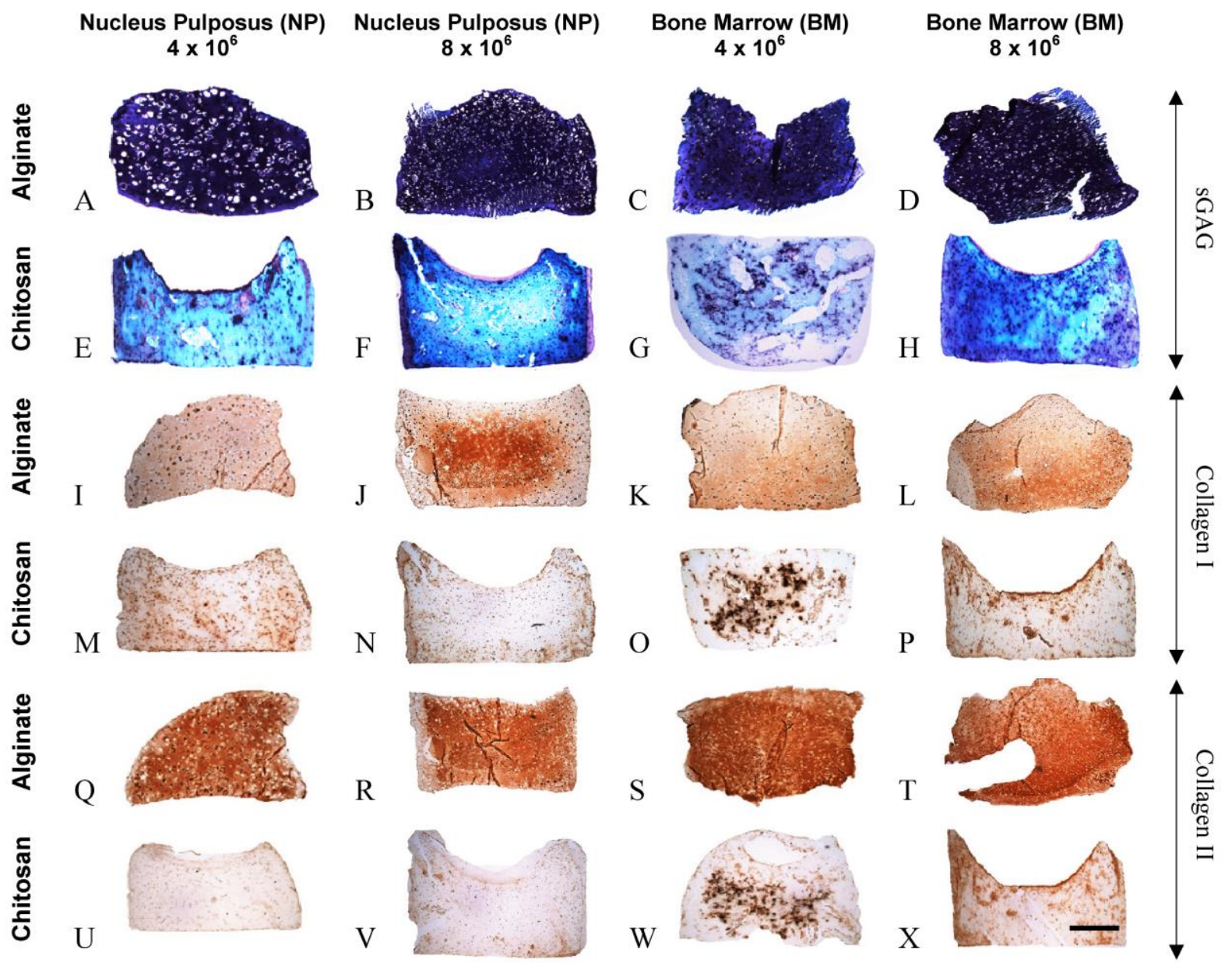

Fig. 3: Histological evaluation at day 21 for nucleus pulposus (NP) and bone marrow stem cells $(\mathrm{BM})$ in isolation at two different cell seeding densities $\left(4 \times 10^{6}\right.$ cells $/ \mathrm{ml}$ and $8 \times 10^{6}$ cells/ml). Sections were stained with aldehyde fuchsin and alcian blue to identify sGAG; (AD) In alginate constructs, deep purple staining indicates GAG accumulation and light blue staining indicates residual alginate, $(\mathrm{E}-\mathrm{H})$ deep purple and cyan blue staining in chitosan indicate GAG accumulation. (I-P) Immunohistochemistry for Collagen I. (Q-X) Immunohistochemistry for Collagen II. Scale bar $=1 \mathrm{~mm}$ 


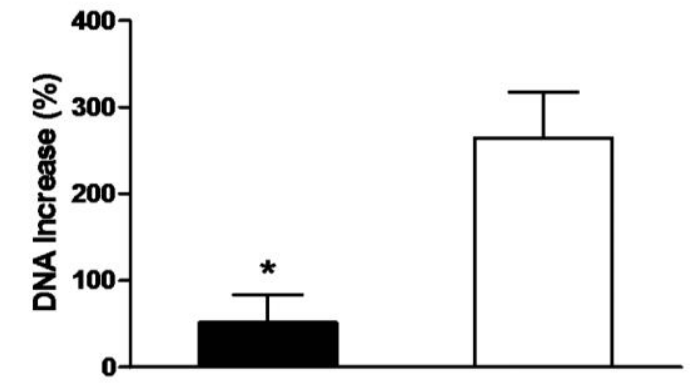

A

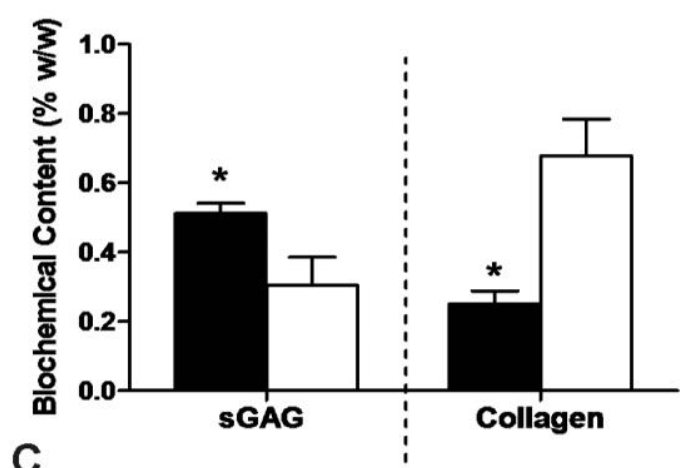

C
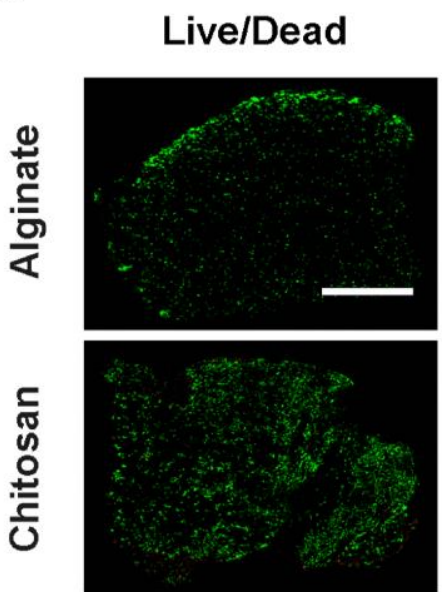

E

$\mathbf{F}$
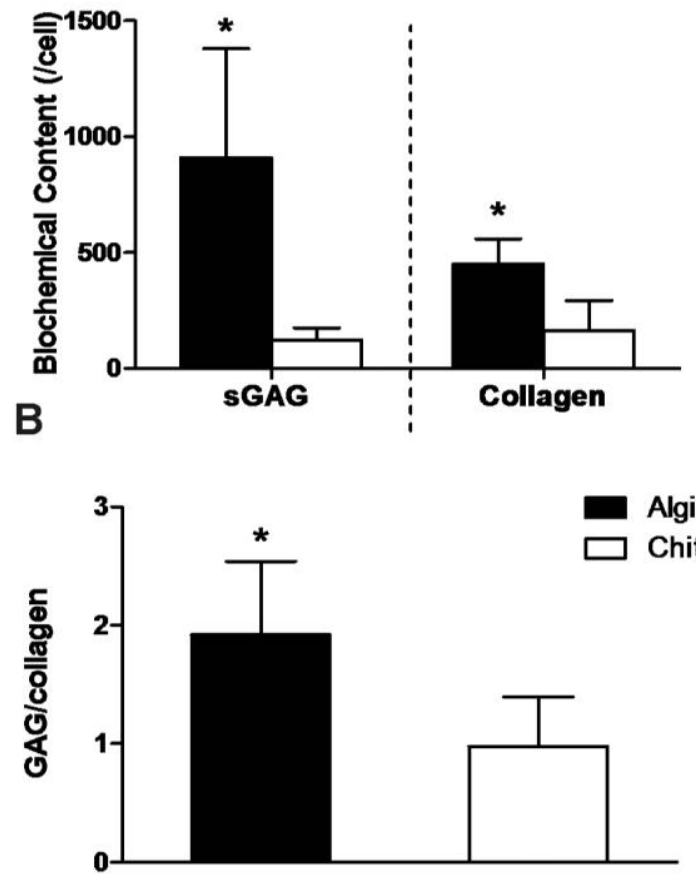

Collagen I

Collagen II
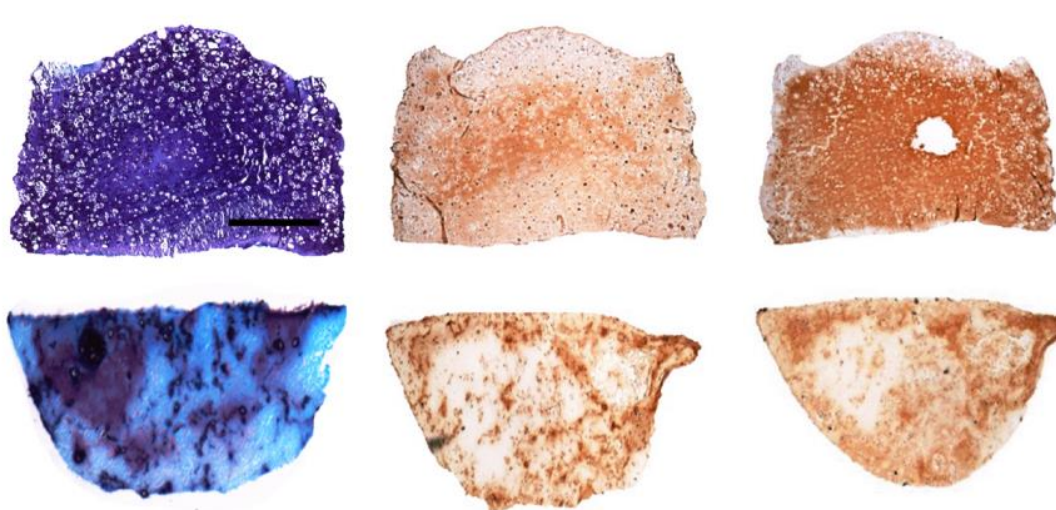

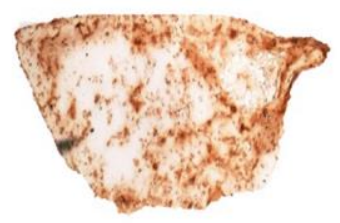

G

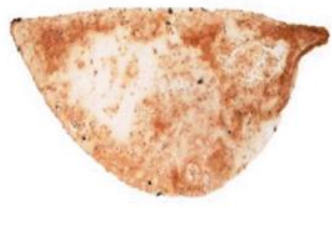

H

Fig. 4: Co-culture of nucleus pulposus (NP) and bone marrow stem cells (BM) in alginate and chitosan hydrogels. (A) Percentage DNA increase at day 21 for co-culture of NP and BM (final seeding density $=8 \times 10^{6}$ cells $/ \mathrm{ml}$ ). (B) sGAG and Collagen content normalised on a per cell basis at day 21. (C) sGAG and Collagen content normalised to wet weight at day 21 . (D) sGAG:Collagen ratio at day 21 * denotes significance; $p<0.05$ compared to chitosan; data represents mean $\pm \mathrm{SD}(\mathrm{n}=6)$. (E) Cell viability at day 21 for co-culture of nucleus pulposus (NP) and bone marrow stem cells (BM); green fluorescence indicates viable cells (Calcein) and red indicates dead cells (Ethidium Homodimer-1). Scale bar =1mm. (F) sGAG 
histological evaluation. Sections were stained with aldehyde fuchsin and alcian blue to identify sGAG; in alginate constructs deep purple staining indicates GAG accumulation and light blue staining indicates residual alginate, deep purple and cyan blue staining in chitosan indicate GAG accumulation. $(\mathrm{G})$ Immunohistochemistry for collagen type I and $(\mathrm{H})$ collagen type II. Scale bar $=1 \mathrm{~mm}$. 


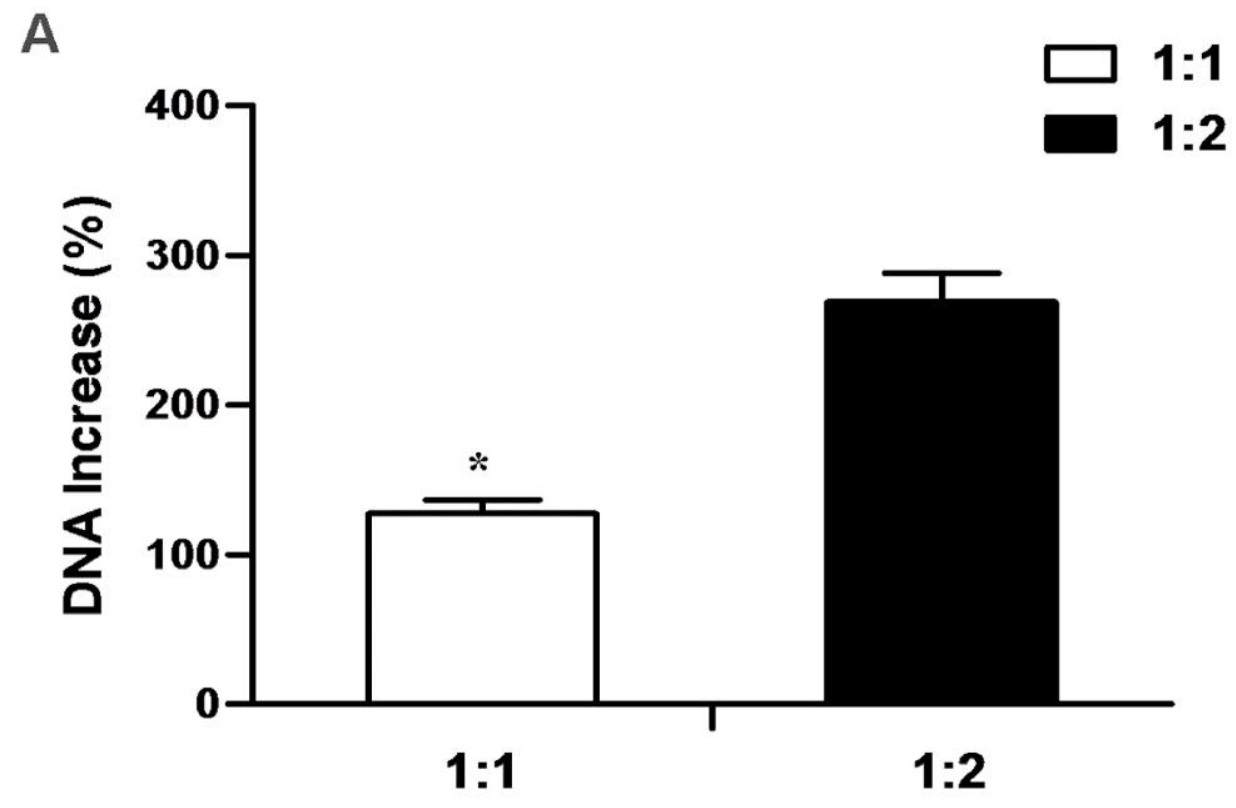

B

NP:BM 1:1 $8 \times 10^{6} / \mathrm{ml}$

NP:BM 1:2 $12 \times 10^{6} / \mathrm{ml}$ Day 0 Day 21
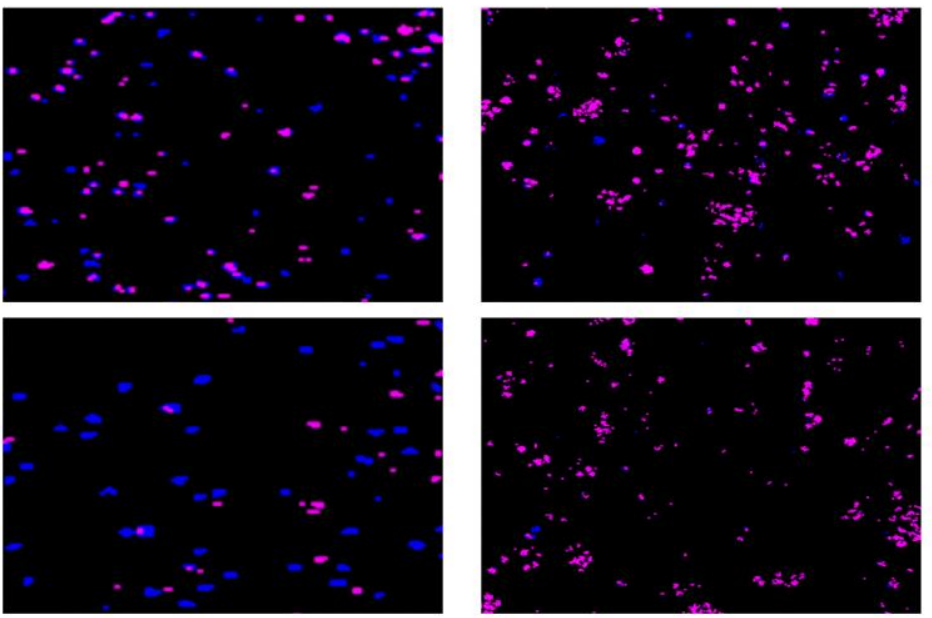

C

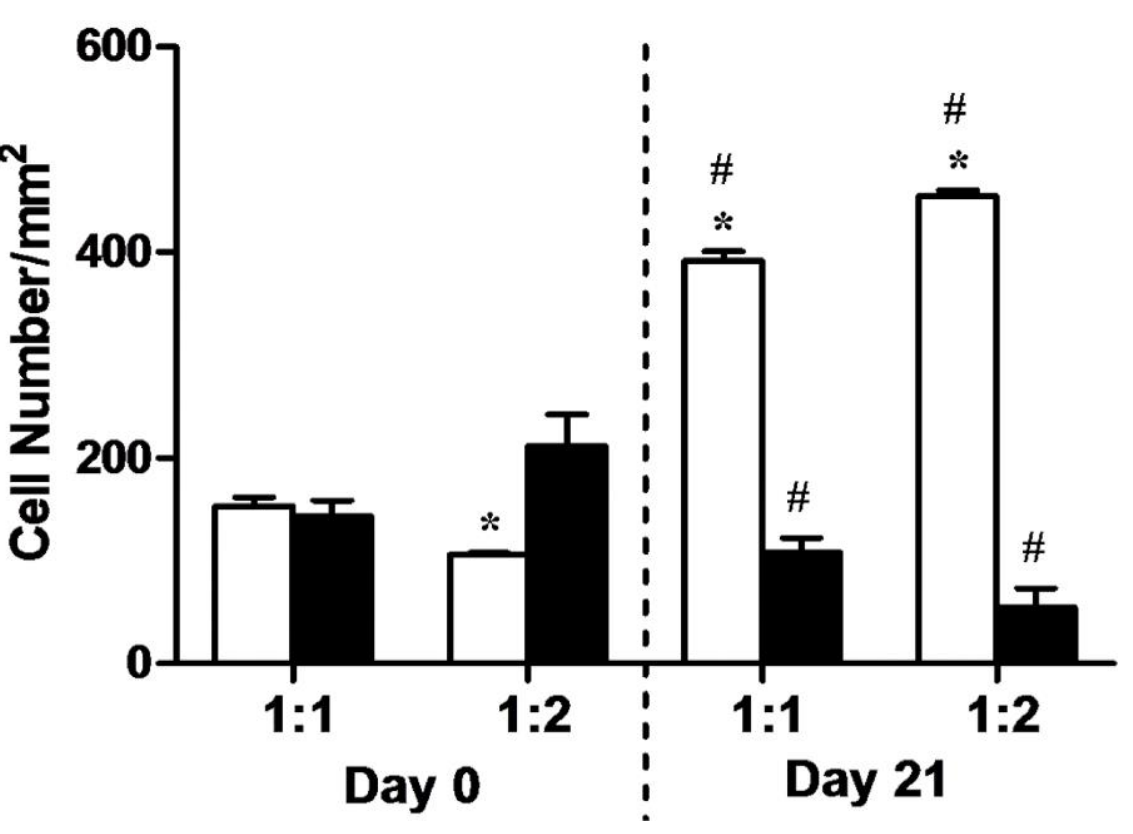

$\square$ NP BM 
Fig. 5: Co-culture of nucleus pulposus (NP) and bone marrow stem cells (BM) in alginate constructs at different cell ratios. (A) Percentage DNA increase at day 21 for co-culture of nucleus pulposus (NP) and bone marrow stem cells (BM) in a ratio of 1:1 (final seeding density $=8 \times 10^{6}$ cells $/ \mathrm{ml}$ ) and 1:2 (final cell seeding density $=12 \times 10^{6}$ cells $/ \mathrm{ml}$ ); * denotes significance; $\mathrm{p}<0.05$ compared to ratio of $1: 2$; data represents mean $\pm \mathrm{SD}(\mathrm{n}=3)$. (B) Fluorescent Cell Labelling at day 0 and day 21; magenta fluorescence indicates PKH26 labelled porcine NP cells; blue fluorescence indicates PKH67 labelled porcine BM MSCs. (C) Cell number $/ \mathrm{mm}^{2}$ of NP and BM in $1: 1$ and 1:2 co-culture groups at day 0 and day 21 ; * denotes significance; $\mathrm{p}<0.05$ compared to BM. \# denotes significance $(\mathrm{p}<0.05)$ compared with Day 0. 

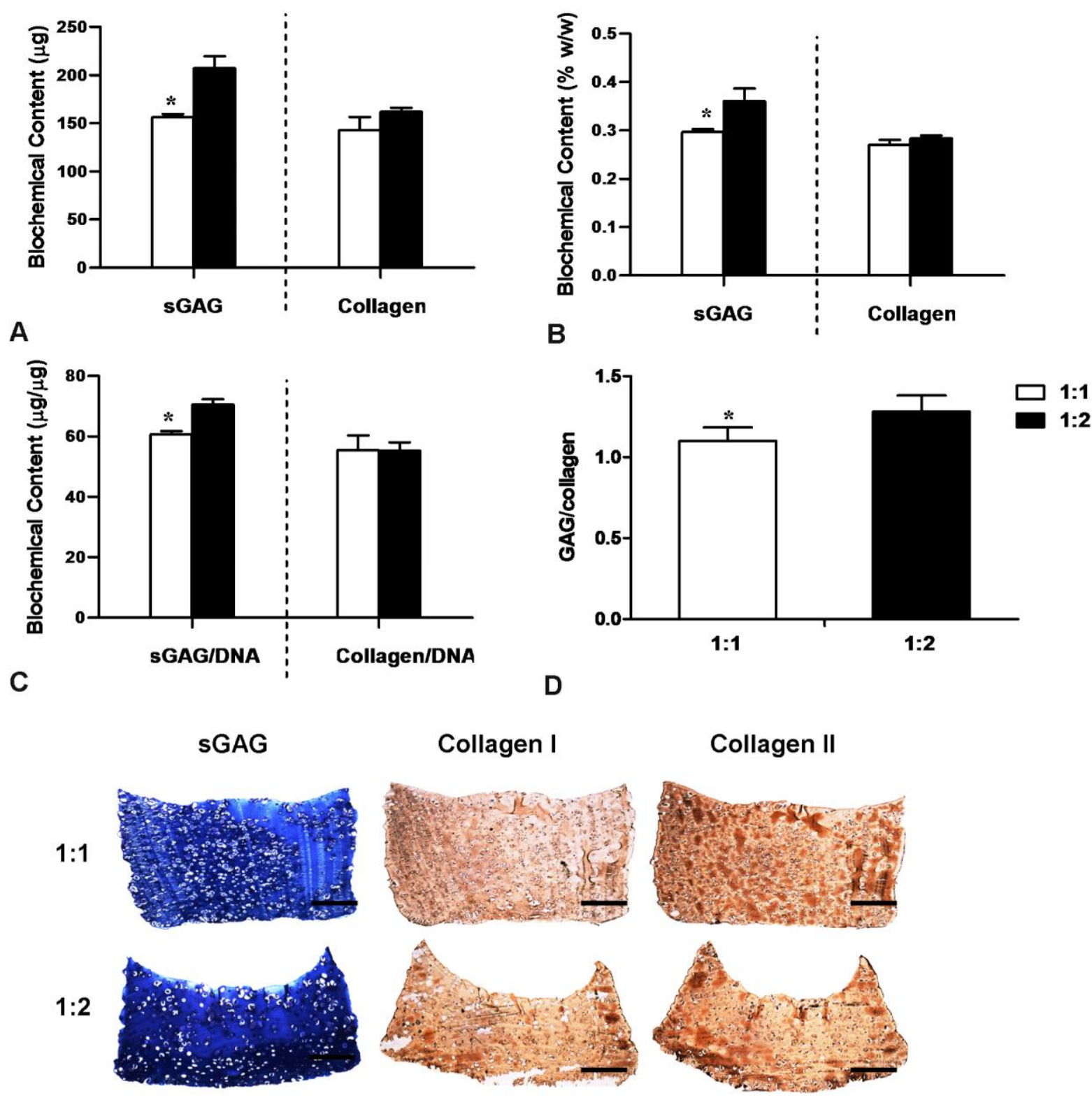

E

Fig. 6: Biochemical analysis at day 21 for co-culture of nucleus pulposus (NP) and bone marrow stem cells $(\mathrm{BM})$ in a ratio of $1: 1$ (final seeding density $=8 \times 10^{6}$ cells $/ \mathrm{ml}$ ) and 1:2 (final cell seeding density $=12 \times 10^{6}$ cells $\left./ \mathrm{ml}\right) ;(\mathrm{A})$ Total sGAG and collagen content $(\mu \mathrm{g})$; (B) Total sGAG and collagen normalized to wet weight (\% w/w); (C) Total sGAG and collagen normalized to DNA $(\mu \mathrm{g} / \mu \mathrm{g})$; (D) sGAG/Collagen ratio. * denotes significance; p<0.05 compared to 1:2 NP:BM. (E) Histological evaluation. Sections were stained with aldehyde fuchsin and alcian blue to identify sGAG; deep purple staining indicates GAG 
accumulation and light blue staining indicates residual alginate; Immunohistochemistry for collagen type I and collagen type II. Scale bar $=1 \mathrm{~mm}$.

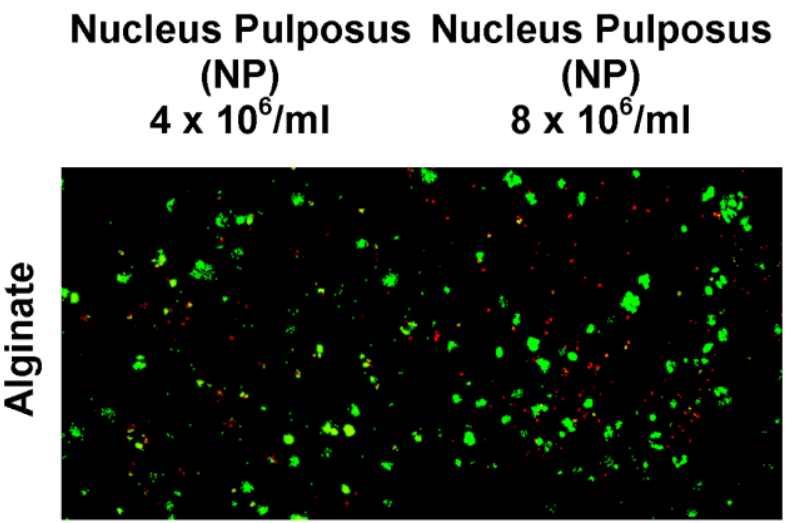

Bone marrow MSC Bone marrow MSC
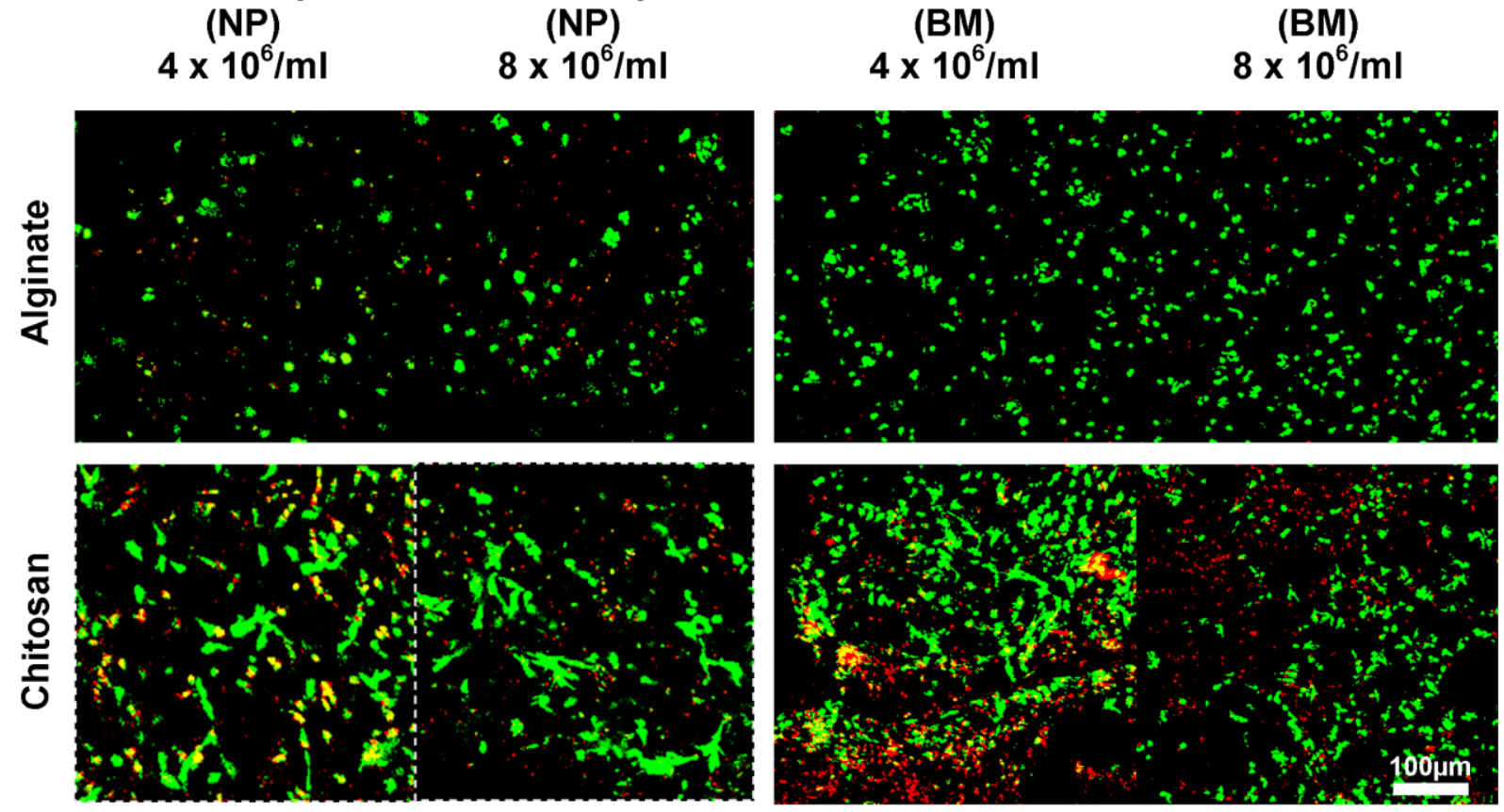

Fig. S1: Cell Morphology of nucleus pulposus (NP) and bone marrow derived MSCs (BM) at two different cell seeding densities $\left(4 \times 10^{6}\right.$ cells $/ \mathrm{ml}$ and $8 \times 10^{6}$ cells $\left./ \mathrm{ml}\right)$ in alginate and chitosan hydrogels, Cell Viability; Green Fluorescence indicates viable cells (Calcein) and red indicates dead cells (Ethidium Homodimer-1). Scale bar $=100 \mu \mathrm{m}$. 


\section{References}

1. Martin JA, Buckwalter JA. Aging, articular cartilage chondrocyte senescence and osteoarthritis. Biogerontology.3:257-64. 2002.

2. Taylor TK, Melrose J, Burkhardt D, Ghosh P, Claes LE, Kettler A, et al. Spinal biomechanics and aging are major determinants of the proteoglycan metabolism of intervertebral disc cells. Spine (Phila Pa 1976).25:3014-20. 2000.

3. Kandel RA, Hamilton D, Seguin C, Li SQ, Arana C, Pilliar R. An in vitro tissue model to study the effect of age on nucleus pulposus cells. Eur Spine J.16:2166-73. 2007.

4. Perrien DS, Akel NS, Dupont-Versteegden EE, Skinner RA, Siegel ER, Suva LJ, et al. Aging alters the skeletal response to disuse in the rat. Am J Physiol Regul Integr Comp Physiol.292:R988-96. 2007.

5. Dudhia J, Scott CM, Draper ER, Heinegard D, Pitsillides AA, Smith RK. Aging enhances a mechanically-induced reduction in tendon strength by an active process involving matrix metalloproteinase activity. Aging Cell.6:547-56. 2007.

6. Korecki CL, Kuo CK, Tuan RS, Iatridis JC. Intervertebral disc cell response to dynamic compression is age and frequency dependent. J Orthop Res.27:800-6. 2009.

7. Le Maitre CL, Freemont AJ, Hoyland JA. Accelerated cellular senescence in degenerate intervertebral discs: a possible role in the pathogenesis of intervertebral disc degeneration. Arthritis Res Ther.9:R45. 2007.

8. Gruber HE, Ingram JA, Norton HJ, Hanley EN, Jr. Senescence in cells of the aging and degenerating intervertebral disc: immunolocalization of senescence-associated betagalactosidase in human and sand rat discs. Spine (Phila Pa 1976).32:321-7. 2007.

9. Meisel HJ, Ganey T, Hutton WC, Libera J, Minkus Y, Alasevic O. Clinical experience in cell-based therapeutics: intervention and outcome. Eur Spine J.15 Suppl 3:S397-405. 2006. 
10. Okuma M, Mochida J, Nishimura K, Sakabe K, Seiki K. Reinsertion of stimulated nucleus pulposus cells retards intervertebral disc degeneration: an in vitro and in vivo experimental study. J Orthop Res.18:988-97. 2000.

11. Gruber HE, Johnson TL, Leslie K, Ingram JA, Martin D, Hoelscher G, et al. Autologous intervertebral disc cell implantation: a model using Psammomys obesus, the sand rat. Spine (Phila Pa 1976).27:1626-33. 2002.

12. Richardson SM, Hoyland JA. Stem cell regeneration of degenerated intervertebral discs: current status. Curr Pain Headache Rep.12:83-8. 2008.

13. Wu J, Wang D, Ruan D, He Q, Zhang Y, Wang C, et al. Prolonged expansion of human nucleus pulposus cells expressing human telomerase reverse transcriptase mediated by lentiviral vector. J Orthop Res.1:159-66. 2014.

14. Le Maitre CL, Baird P, Freemont AJ, Hoyland JA. An in vitro study investigating the survival and phenotype of mesenchymal stem cells following injection into nucleus pulposus tissue. Arthritis Res Ther.11:R20. 2009.

15. Nomura T, Mochida J, Okuma M, Nishimura K, Sakabe K. Nucleus pulposus allograft retards intervertebral disc degeneration. Clin Orthop Relat Res.389:94-101. 2001.

16. Pittenger MF, Mosca JD, McIntosh KR. Human mesenchymal stem cells: progenitor cells for cartilage, bone, fat and stroma. Curr Top Microbiol Immunol.251:3-11. 2000.

17. Richardson SM, Hughes N, Hunt JA, Freemont AJ, Hoyland JA. Human mesenchymal stem cell differentiation to NP-like cells in chitosan-glycerophosphate hydrogels. Biomaterials.29:85-93. 2008.

18. Risbud MV, Albert TJ, Guttapalli A, Vresilovic EJ, Hillibrand AS, Vaccaro AR, et al. Differentiation of mesenchymal stem cells towards a nucleus pulposus-like phenotype in vitro: implications for cell-based transplantation therapy. Spine (Phila Pa 1976).29:2627-32. 2004. 
19. Crevensten G, Walsh AJ, Ananthakrishnan D, Page P, Wahba GM, Lotz JC, et al. Intervertebral disc cell therapy for regeneration: mesenchymal stem cell implantation in rat intervertebral discs. Ann Biomed Eng.32:430-4. 2004.

20. Sakai D, Mochida J, Yamamoto Y, Nomura T, Okuma M, Nishimura K, et al. Transplantation of mesenchymal stem cells embedded in Atelocollagen gel to the intervertebral disc: a potential therapeutic model for disc degeneration. Biomaterials.24:353141. 2003.

21. Yamamoto Y, Mochida J, Sakai D, Nakai T, Nishimura K, Kawada H, et al. Upregulation of the viability of nucleus pulposus cells by bone marrow-derived stromal cells: significance of direct cell-to-cell contact in coculture system. Spine (Phila Pa 1976).29:150814. 2004.

22. Richardson SM, Walker RV, Parker S, Rhodes NP, Hunt JA, Freemont AJ, et al. Intervertebral disc cell-mediated mesenchymal stem cell differentiation. Stem Cells.24:70716. 2006.

23. Le Visage C, Kim SW, Tateno K, Sieber AN, Kostuik JP, Leong KW. Interaction of human mesenchymal stem cells with disc cells: changes in extracellular matrix biosynthesis. Spine (Phila Pa 1976).31:2036-42. 2006.

24. Vadala G, Studer RK, Sowa G, Spiezia F, Iucu C, Denaro V, et al. Coculture of bone marrow mesenchymal stem cells and nucleus pulposus cells modulate gene expression profile without cell fusion. Spine (Phila Pa 1976).33:870-6. 2008.

25. Stevens MM, Qanadilo HF, Langer R, Prasad Shastri V. A rapid-curing alginate gel system: utility in periosteum-derived cartilage tissue engineering. Biomaterials.25:887-94. 2004.

26. Chandy T, Sharma CP. Chitosan--as a biomaterial. Biomater Artif Cells Artif Organs.18:1-24. 1990. 
27. Ge Z, Baguenard S, Lim LY, Wee A, Khor E. Hydroxyapatite-chitin materials as potential tissue engineered bone substitutes. Biomaterials.25:1049-58. 2004.

28. Kuo CK, Ma PX. Ionically crosslinked alginate hydrogels as scaffolds for tissue engineering: part 1. Structure, gelation rate and mechanical properties. Biomaterials.22:51121. 2001.

29. Gantenbein-Ritter B, Chan SC. The evolutionary importance of cell ratio between notochordal and nucleus pulposus cells: an experimental 3-D co-culture study. Eur Spine J.21 Suppl 6:S819-25. 2012.

30. Chou AI, Akintoye SO, Nicoll SB. Photo-crosslinked alginate hydrogels support enhanced matrix accumulation by nucleus pulposus cells in vivo. Osteoarthritis Cartilage.17:1377-84. 2009.

31. Leone G, Torricelli P, Chiumiento A, Facchini A, Barbucci R. Amidic alginate hydrogel for nucleus pulposus replacement. J Biomed Mater Res A.84:391-401. 2008.

32. Xu J, Wang W, Ludeman M, Cheng K, Hayami T, Lotz JC, et al. Chondrogenic differentiation of human mesenchymal stem cells in three-dimensional alginate gels. Tissue Eng Part A.14:667-80. 2008.

33. Ma HL, Hung SC, Lin SY, Chen YL, Lo WH. Chondrogenesis of human mesenchymal stem cells encapsulated in alginate beads. J Biomed Mater Res A.64:273-81. 2003.

34. Roughley P, Hoemann C, DesRosiers E, Mwale F, Antoniou J, Alini M. The potential of chitosan-based gels containing intervertebral disc cells for nucleus pulposus supplementation. Biomaterials.27:388-96. 2006.

35. Spillekom S, Smolders LA, Grinwis GC, Arkesteijn IT, Ito K, Meij BP, et al. Increased Osmolarity and Cell Clustering Preserve Canine Notochordal Cell Phenotype in Culture. Tissue Eng Part C Methods.20:8. 2014. 
36. Thorpe SD, Buckley CT, Vinardell T, O'Brien FJ, Campbell VA, Kelly DJ. The response of bone marrow-derived mesenchymal stem cells to dynamic compression following tgf- $\beta 3$ induced chondrogenic differentiation. Annals of Biomedical Engineering.38:2896-909. 2010.

37. Buckley CT, Kelly DJ. Expansion in the presence of FGF-2 enhances the functional development of cartilaginous tissues engineered using infrapatellar fat pad derived MSCs. J Mech Behav Biomed Mater.11:102-11. 2012.

38. Hoemann CD, Sun J, Chrzanowski V, Buschmann MD. A multivalent assay to detect glycosaminoglycan, protein, collagen, RNA, and DNA content in milligram samples of cartilage or hydrogel-based repair cartilage. Anal Biochem.300:1-10. 2002.

39. Kafienah W, Sims TJ. Biochemical methods for the analysis of tissue-engineered cartilage. Methods Mol Biol.238:217-30. 2004.

40. Ignat'eva NY, Danilov N, Averkiev S, Obrezkova M, Lunin V, Sobol, Äô E. Determination of hydroxyproline in tissues and the evaluation of the collagen content of the tissues. Journal of Analytical Chemistry.62:51-7. 2007.

41. Hoemann CD, Sun J, Legare A, McKee MD, Buschmann MD. Tissue engineering of cartilage using an injectable and adhesive chitosan-based cell-delivery vehicle. Osteoarthritis Cartilage.13:318-29. 2005.

42. Simmons CA, Alsberg E, Hsiong S, Kim WJ, Mooney DJ. Dual growth factor delivery and controlled scaffold degradation enhance in vivo bone formation by transplanted bone marrow stromal cells. Bone.35:562-9. 2004.

43. Mwale F, Roughley P, Antoniou J. Distinction between the extracellular matrix of the nucleus pulposus and hyaline cartilage: a requisite for tissue engineering of intervertebral disc. Eur Cell Mater.8:58-63. 2004. 
44. Meisel HJ, Siodla V, Ganey T, Minkus Y, Hutton WC, Alasevic OJ. Clinical experience in cell-based therapeutics: disc chondrocyte transplantation A treatment for degenerated or damaged intervertebral disc. Biomol Eng.24:5-21. 2007.

45. Vadala G, Sowa G, Hubert M, Gilbertson LG, Denaro V, Kang JD. Mesenchymal stem cells injection in degenerated intervertebral disc: cell leakage may induce osteophyte formation. J Tissue Eng Regen Med.6:348-55. 2012.

46. Urban JP. The role of the physicochemical environment in determining disc cell behaviour. Biochem Soc Trans.30:858-64. 2002.

47. McCanless JD, Cole JA, Slack SM, Bumgardner JD, Zamora PO, Haggard WO. Modeling nucleus pulposus regeneration in vitro: mesenchymal stem cells, alginate beads, hypoxia, bone morphogenetic protein-2, and synthetic peptide B2A. Spine (Phila Pa 1976).36:2275-85. 2011.

48. Chiba K, Andersson GB, Masuda K, Thonar EJ. Metabolism of the extracellular matrix formed by intervertebral disc cells cultured in alginate. Spine (Phila $\mathrm{Pa}$ 1976).22:2885-93. 1997.

49. Renani HB, Ghorbani M, Beni BH, Karimi Z, Mirhosseini M, Zarkesh H, et al. Determination and comparison of specifics of nucleus pulposus cells of human intervertebral disc in alginate and chitosan-gelatin scaffolds. Adv Biomed Res.1:81. 2012.

50. Wang L, Shelton RM, Cooper PR, Lawson M, Triffitt JT, Barralet JE. Evaluation of sodium alginate for bone marrow cell tissue engineering. Biomaterials.24:3475-81. 2003.

51. Venkatesan J, Kim SK. Chitosan composites for bone tissue engineering--an overview. Mar Drugs.8:2252-66. 2010.

52. Bacakova L, Filova E, Rypacek F, Svorcik V, Stary V. Cell adhesion on artificial materials for tissue engineering. Physiol Res.53 Suppl 1:S35-45. 2004. 
53. Dadsetan M, Pumberger M, Casper ME, Shogren K, Giuliani M, Ruesink T, et al. The effects of fixed electrical charge on chondrocyte behavior. Acta Biomater.7:2080-90. 2011.

54. Kwon HJ, Yasuda K, Ohmiya Y, Honma K, Chen YM, Gong JP. In vitro differentiation of chondrogenic ATDC5 cells is enhanced by culturing on synthetic hydrogels with various charge densities. Acta Biomater.6:494-501. 2010.

55. Liu JF, Chen YM, Yang JJ, Kurokawa T, Kakugo A, Yamamoto K, et al. Dynamic behavior and spontaneous differentiation of mouse embryoid bodies on hydrogel substrates of different surface charge and chemical structures. Tissue Eng Part A.17:2343-57. 2011.

56. Mathieu PS, Loboa EG. Cytoskeletal and focal adhesion influences on mesenchymal stem cell shape, mechanical properties, and differentiation down osteogenic, adipogenic, and chondrogenic pathways. Tissue Eng Part B Rev.18:436-44. 2012.

57. Guaccio A, Borselli C, Oliviero O, Netti PA. Oxygen consumption of chondrocytes in agarose and collagen gels: a comparative analysis. Biomaterials.29:1484-93. 2008.

58. Allon AA, Butcher K, Schneider RA, Lotz JC. Structured coculture of mesenchymal stem cells and disc cells enhances differentiation and proliferation. Cells Tissues Organs.196:99-106. 2012.

59. Gaetani P, Torre ML, Klinger M, Faustini M, Crovato F, Bucco M, et al. Adiposederived stem cell therapy for intervertebral disc regeneration: an in vitro reconstructed tissue in alginate capsules. Tissue Eng Part A.14:1415-23. 2008.

60. Strassburg S, Richardson SM, Freemont AJ, Hoyland JA. Co-culture induces mesenchymal stem cell differentiation and modulation of the degenerate human nucleus pulposus cell phenotype. Regen Med.5:701-11. 2010.

61. Scuteri A, Donzelli E, Rodriguez-Menendez V, Ravasi M, Monfrini M, Bonandrini B, et al. A double mechanism for the mesenchymal stem cells' positive effect on pancreatic islets. PLoS One.9:e84309. 2014. 
62. Alini M, Eisenstein SM, Ito K, Little C, Kettler AA, Masuda K, et al. Are animal models useful for studying human disc disorders/degeneration? Eur Spine J.17:2-19. 2008.

63. Choi KS, Cohn MJ, Harfe BD. Identification of nucleus pulposus precursor cells and notochordal remnants in the mouse: implications for disk degeneration and chordoma formation. Dev Dyn.237:3953-8. 2008.

64. Gotz W, Kasper M, Fischer G, Herken R. Intermediate filament typing of the human embryonic and fetal notochord. Cell Tissue Res.280:455-62. 1995. 